\title{
EFL Teachers' Professional Development: Towards a Counterpart of the English Language Supremacy'
}

\section{Desarrollo Profesional de los Docentes de Inglés: Hacia una contraparte de la Supremacía del Idioma Inglés}

\begin{abstract}
This article aims at contributing to the ongoing discussion about the English language Supremacy and its influence in the EFL field. The theoretical discussion presented is retrieved from the literature reviewed in the development of the authors' master thesis, where it was possible to identify that there are ideological, economical, and sociopolitical aspects immersed in the decision to learn and use English, having as a result that EFL teachers' educational decisions and practices have been affected. Thereupon, the main contribution of this reflection article is, then, to explore from a theoretical perspective, a resistance discourse that promotes professional development by understanding and reflecting upon the colonial ideas in which this foreign language teaching has been immersed over the years.
\end{abstract}

Key words: English supremacy, colonial discourse, professional development, NES vs NNEST

\section{Resumen}

Este artículo tiene como objetivo contribuir en la discusión continua acerca de la supremacía de la lengua inglesa y su influencia en el campo de la enseñanza del Inglés como lengua extranjera. La discusión teórica presentada es tomada

\footnotetext{
Received: March 31st 2018/ Accepted: October 30th 2018

2 auram71894@gmail.com; jennifercita193@gmail.com
} 
de la literatura revisada durante el desarrollo de las tesis de maestría de las autoras, en donde es posible identificar la existencia de aspectos ideológicos, económicos y sociopolíticos inmersos en la decisión de aprender y usar la lengua inglesa que han afectado las prácticas y decisiones de los profesores de Inglés. En este sentido, la contribución principal de este artículo de reflexión es explorar desde una perspectiva teórica, un discurso de resistencia que promueva el desarrollo profesional docente por medio del entendimiento y la reflexión acerca de las ideas coloniales inmersas en la enseñanza de ésta lengua extranjera a lo largo del tiempo.

Palabras Clave: Supremacía Inglesa, discurso colonial, desarrollo profesional, NES vs NNEST

\section{Resumo}

Este artigo tem como objetivo contribuir na discussão contínua acerca da supremacia da língua inglesa e a sua influência no campo do ensino do inglês como língua estrangeira. A discussão teórica apresentada é tomada da literatura revisada durante o desenvolvimento das teses de mestrado das autoras, donde foi possível identificar que a língua inglesa tem predominado sobre outros idiomas devido a aspectos ideológicos, econômicos e sociopolíticos. Como resultado, a diferenciação feita entre NES / NNES (Falante de Inglês nativo e não nativo) tem incrementado, afetando as práticas e decisões dos professores de inglês como língua estrangeira (Camargo, 2017; Estacio, 2017). Neste sentido, a contribuição principal deste artigo de reflexão é explorar desde una perspectiva teórica, um discurso de resistência em termos de Desenvolvimento Profissional Docente para entender, refletir e atuar frente às ideias coloniais imersas no ensino desta língua estrangeira ao longo do tempo.

Palavras chave: Aprendizagem invertida, aprendizagem ativa, papel ativo, EFL, percepções 


\section{Introduction}

7 hroughout history, teaching and learning have been assumed as single processes with a beginning and an end (Wenger, 1999). Under this assumption, a linear view of pedagogical approaches and methodologies have been embraced regardless of individuals' realities and experiences (Ayala Zárate \& Álvarez, 2005; Fandiño-Parra, 2014; González, 2007; Guerrero, 2008). This view has been reflected mainly in policies, metrics, training programs, and curriculum designs aiming at outlining and controlling the society (Popkewitz, 2000).

In view of the above, language has been a determinant factor in the construction of that "pre-conceived" society, since its dynamic nature-created, understood, shaped, and validated within a community in a specific context by means of interaction- has allowed some nations to take control over others and assure a privileged position in regards to politics, economy, and sociocultural issues (Fairclough, 2003). As a result, English as a foreign language gained the distinction of being a global language (Crystal, 2003) and was quickly spread along with certain practices and ideologies-that has not only had a linguistic impact- but also sociocultural implications (Camargo, 2017; Estacio, 2017).

In this sense, language policies adopted by governments from monolingual contexts as Colombia, meant to spread the English language under the premise of allowing non-native speakers (NNES) to have access to a world ruled by globalization where they can communicate and break boundaries of language and culture (BruttGriffler, 2002). Yet, the distinction made between native and non-native speakers has affected not only the attitudes of all the actors involved in English education towards the language, but has had an impact on the teaching and learning language practices around the world (Bhowmik, 2015; Ramanathan, 2013).

These effects can be easily recognized in monolingual countries where the mother tongue and other languages spoken in these countries have been suppressed or displaced by English (Tollefson, 2000; Ryan, 2010) so their citizens can be considered as bilinguals. Notwithstanding, the conception of bilingualism held by countries such as ours, was reduced to the fact of speaking English as it has been stated by different authors (Guerrero, 2008; Usma, 2009; De Mejía, 2011; Ordoñez, 2011; Escobar, 2013; Sánchez \& Obando, 2008). As a consequence, NNES in general have faced struggles towards the ownership of the language and the recognition of speaking it, being forced to "hide their intellectual 
and communicative capabilities under a bushel" (Kohn, 2011, p. 71) which means that their intellectual capabilities are being disregarded when they decide to use their mother language instead of English.

Moreover, Camargo, (2017) and Pineda (2001) have said EFL teachers' decisions on methodology, curriculum, syllabus and material design have been limited, as their role has been relegated as of trainers since NES are believed to be the source of understanding and capability in terms of EFL educational practices. However, by thinking about the historical and sociocultural implications of certain decisions, EFL teachers are called to resist colonial and hegemonic discourses so as to transform their educational practices and endorse their professional development (Camargo 2017, Estacio, 2017).

Thereby, in this reflective article, we intend to ponder upon the ideological and social background of the English language to first, understand how it has become into the artifact to trigger sociocultural ideas on its users, and secondly, the effects its supremacy has had in EFL teachers and the way of resisting them.

\section{Ideological and Social background of a Hegemonic Language}

As previously stated, considering English as an international language, may have implications in the linguistics field, however, as authors such as Mahboob (2005) have stated, it also has cultural, political and economic implications. Ergo, it has been mostly promoted as the one that allows people to build society and to fetch better economic and academic prospects (Barkhuizen, 2002).

Considering Mignolo (2009), the colonial expansion of the British and American population to different territories around the world in the 18th and 19th centuries had a powerful impact regarding the imposition of the English language in territories where the mother tongue was a different one. To start with, the policies set in the field of educationby the colonial powers- controlled the intellectual production in the English language while dismissing the one given in the vernacular ones (Quijano, 1992). This decision in view of Pennycook (2004), had

218 not only linguistic implications, but it has also caused struggles for dominance against other languages.

Then, around the I World War, it was felt in such a manner that languages were one of the roots of international conflict, that private institutions started to pay for academic exchanges between the US and the countries involved in the war. The intention was to join efforts to devise simplified forms of English and make easier international 
understanding (Ninkovich as cited in Phillipson, 1992). Hence, knowledge regarding this language was crucial for studying fields such us science, technology and engineering (White, 1965), and its active use for different social purposes, shaped the discourse in which the native speaker is seen as the ideal speaker in the educational sphere (Estacio, 2017).

In this sense, native English speakers (NES) -specially from North America and England- gained a privileged position in the language teaching field based on the fact that the language variation they used, was considered as the epitome and the gold standard (Walkinshaw \& Oanh, 2014). Thereby, they were assumed to be the correct way of speaking and the basis of the language teaching (Davies, 2003).

Moreover, at the end of the World War II, the idea of an ideal variation, mostly diffused by the British Council, allowed domination and ideological control as the language was molded for political and ideological plans (Canagarajah, 1999). Similarly, it aimed at publicizing a general understanding of the British culture, which in view of Phillipson (1992), meant nothing but to make foreign speakers anglophiles under the ideal of being accepted in an eminent society by means of using a British English variation- symbol of power and educational status worldwide (Shohamy, 2006).

Because of that, propaganda activities in the outer circle countries (Kachru, 1985) were frequently carried out by a body of executives and educational experts belonging to the British Council. As a result, this institution started to be treated as the supreme authority in the EFL sphere, a premise that up to now, is considered to be unmistakable. Bearing this in mind, it can be said that the aim of this entity has not only be given in terms of education but also economy, commerce and governmental ones. Whence, teaching and learning English has been seen as a means to commercialize English books, advertise a culture, and embrace a definite accent variation.

From this perspective, a phenomenon called "schizoglossia" appeared among NNES. It derived from the notion of not having an accent as good as the standard one so, they need to simulate and reach the native-like accent to improve their communication and of course, avoid linguistic misunderstandings (Baker, 2006). This led to the imposed belief of having a standardized language that allows both NES and NNES to communicate "ideally" (Crystal, 2003).

However, this language standardization grounded on ideological structures aiming at preserving the perfection and purity of the language (Lippi-Green, 2012) has also looked forward reproducing homogeneity 
in social behavior (Guerrero \& Quintero, 2009). As a result, these hegemonic ideas by being experienced as absolute reality, have influenced the thoughts, decisions, and actions of all the actors involved in the language field (Tollefson, 2000). Hence, based on the historical facts previously described, it is possible to see that the predominance of a language variation that exists nowadays, is rooted on different events along the history that have placed the native variation in a privileged position as opposed to the non-native English variations.

\section{The NES / NNES Dichotomy: Implications in the EFL field}

Considering the above, there are ideological and social choices immersed when making the decision to learn and use English. Such choice draws upon the new capitalism notion, in which an excessive consumerism and competition are the result of an economic system that has had incidence towards the way English language should be taught, learned, and spoken (Fairclough 2003). For instance, methodologies and materials created by NES are used in NNES nations as the perfect recipe to make learners speak the language, but those materials offer not only a linguistic knowledge but also, a socio-cultural lifestyle that NNES want to replicate.

In accordance with Foucault (2005), education is the chief tool to effect power through systems of knowledge. Thus, theories, methodologies, curricula, materials and topics, are used as pillars for molding educational actors' view of the world (Popkewitz, 2000; González \& Sierra, 2005). Subsequently, teaching and learning English has been portrayed as the only solution through which citizens from the outer and expanding circles (Kachru, 1985) can access to a "qualified" education to then obtain a well-paid job, great opportunities, and of course, a more desirable life, similar to the ones developed nations have (Camargo, 2017).

However, Tollefson (2000) reported that for the citizens who belong to the inner circle (Kachru, 1985), the economic value of having English as their mother tongue means inordinate opportunities in education, business and employment (Usma, 2009; Valencia, 2013). On the contrary, the spread of English presents a huge obstacle in the same areas for the ones who have to learn the language since their diverse linguistic varieties are not recognized as legitimate, reason why they have to be constantly evaluated (Kohn, 2011).

In the same line of though, Lowenberg (as cited in Bhowmik, 2015), asserted that notwithstanding NES and NNES interactions are 
more frequent in international communication nowadays, the ELT field keeps on choosing native variations (American and British) as the main language of teaching, strengthening the idea that NES [regardless of their professional background] will ensure the learning process, as the native accent is a determinant factor to learn the language (Sánchez \& Obando, 2008).

This misconception indeed, has had several repercussions on EFL teachers who have always been blamed, questioned, and even replaced (Adriana González, personal communication, June 6, 2015). Likewise, non-native EFL teachers' notion of expertise in terms of curriculum and materials design has got narrowed and minimized because of the existence of beliefs in which native speakers represent a source of knowledge and skillfulness in terms of English language pedagogy (Camargo, 2017).

As a matter of fact, researchers in countries where English has been taught and evaluated under already defined standards have discovered similar findings. For example, Muthanna \& Karaman (2011) stated teachers' beliefs concerning EFL Education were dismissed as have scarcity of well-defined standards and philosophy statements. What is more, education policy-makers disregarded the ideas and strategies suggested by teachers' in order to improve the EFL curriculum in Yemen. Alike, Jóhanneson et. al (2000) affirmed teachers' notion of expertise got narrowed as there are pre-defined standards and goals; and Barkhuizen's (2002) study showed that when decisions about educational issues are made, teachers and students' points of view are often ignored, though these last ones have a preference for studying English over the native language since it has been said, would give them better life opportunities.

As seen, these discourses and practices have voided teachers' role as designers, managers and evaluators of curricula and materials (Camargo, 2017). Besides, local research into bilingualism and foreign languages pedagogy is overshadowed (De Mejía, 2004). Likewise, it has had a great influence on the way English is being taught in educational institutions (Guerrero \& Quintero, 2009; p. 137).

Hence, the EFL professional development term under this perspective, has been limited to the conceptions of teacher-training programs in which the emphasis is on reviewing and memorizing approaches, methodologies or theories that others had developed at the time of increasing teachers' proficiency in the foreign language (González, 2009; Guerrero, 2008). 
Indeed, most - if not all- of the updating/training programs are offered by foreign entities and $N E S$, who as previously mentioned, are chosen over EFL teachers for their "proper" pronunciation, perpetuating the conception of neutrality given to the native variation (Guerrero \& Quintero, 2009) and validating the notion that there is one way of teaching notwithstanding of contexts, realities and learners. As a result, EFL educational actors are subjected to learn and teach this language while being positioned as followers (Camargo, 2017).

\section{Developing the Supremacy Counterpart}

Although the linguistic imperialism and dominance of the English language has lasted and affected diverse aspects, there is a desire to combat it. The thesis of a counterpart to the supremacy of English as a means to resist hegemony has in fact emerged from many places around the world and has sought balancing the theory-practice dichotomy and encouraging educators to continue growing both professional and individually by means of reflecting and sharing upon educational theories and practices (Díaz-Maggioli, 2012).

Paradoxically, as Phillipson (1992) states, not only EFL teacherresearchers have been part of the protesting group, but also some scholars from the core and periphery circles (Kachru, 1985). Graddol (2006) for example, forecasted in his study the end on the foreign language teaching grounded on native speaking models by bearing in mind the current quantity of non-native speakers using the language for academic and non-academic purposes. Alike, Kohn (2011) stated the domination perpetuated by economically and socially empowered countries is crumbling as $N N E S$ have astonishingly increased in numbers.

In monolingual contexts, Camargo (2017) for instance, evidenced how EFL and self-contained teachers become main characters in the education process by questioning, reflecting, and visioning, an outcome supported by Nielsen, Triggs, Clarke \& Collins' (2010) who asserted peer dialogue generates new alternatives to think about the teaching practices and their work with their peers and got self-empowered.

Similarly, Estacio's (2017) study, evidenced that some educational institutions are taking into account the real needs of language learners by including the use of non- standard variations and intercultural contact situations, as they are acknowledging the intelligibility of the language rather than the native standard (Levis, 2005). In such a way, they can implement more realistic pedagogical approaches in which the 
language is seen in real situations that may happen in actual interactions where NNES-NES exchanges are commonplace.

Thence, pedagogical aspects such as curriculum, teaching practices, and educational standards can be modified through reflection and bearing in mind the real world of English communication (Shusterman, 2000). Hitherto, it seems the world will eventually overcome the comparison between native and non-native speakers' norms and accents by taking into account the geographical characteristics and by giving priority to the relevance and intelligibility in the language as advocated by Seidlhofer (2011).

\section{Conclusions}

Taking into account the theoretical discussion held in this reflective article, it seems essential for the educational field to comprehend the political, economic, and historical background of the English language to reflect upon the implications of those decisions in the EFL practices. Considering the arguments presented in this article, it can be asserted that the supremacy of the English language has being mostly linked to economic commodities, favoring this language over others.

What is more, the endless differentiation made between NES and $N N E S$ linguistic variation, has had serious implications in terms of teachers' professional development since it has been mainly understood as to formal education programs instead of pedagogical spaces of sharing and discussing initiatives concerning the teaching-learning the language.

Nevertheless, it was shown educators that can resist these discourses of homogenization and colonialism by reflecting, understanding, and being involved in the creation of curricula, methodologies and educational guidelines that draw upon the real world of English communication notwithstanding the native or nonnative speakers' labels.

Bearing this in mind, this reflective paper not only calls attention to the need of making EFL teachers aware of the discourses and practices behind the teaching-learning English process, but it also highlights the acts of resistance that have emerged in the ELT and EFL fields for deprivatizing our pedagogical practices. 


\section{References}

Ayala Zárate, J., \& Álvarez, J. (2005). A perspective of the implications of the Common European Framework implementation in the Colombian socio-cultural context. Colombian Applied Linguistics Journal, (7), 7-26.

Baker, C. (2006). Bilingualism and Bilingual education as a Problem, Right and Resource. In C. Baker (Ed.), Foundation of Bilingual Education and Bilingualism. (pp. 382-397).Bristol, UK: Multilingual Matters.

Barkhuizen, G. (2002). Language-in-education policy: students' perceptions of the status and role of Xhosa and English. System 30(2002), 499-515.

Bhowmik, S. (2015). World Englishes and English Language Teaching: A Pragmatic and Humanistic Approach. Colombian Applied Linguistics Journal, 17(1), 142-157.

Brutt-Griffler, J. (2002). World English: A study of its development. Clevedon, UK: Multilingual Matters. Cambridge University Press.

Camargo, J.P. (2017). Unveiling EFL and self-contained teachers' discourses on bilingualism within the context of professional development (Master dissertation). Retrieved from http://repository. udistrital.edu.co/bitstream/11349/5651/1/Tesis\%20Jennyfer\%20 Camargo.pdf

Canagarajah, S. (1999). Resisting Linguistic Imperialism in English Teaching. Oxford: Oxford University Press.

Crystal, D. (2003). English as a Global Language. Cambridge: Cambridge University Press.

Davies, A. (2003) The Native Speaker: Myth and Reality. Clevedon, UK: Multilingual Matters.

De Mejía, Anne-Marie. (2004). Bilingual Education in Colombia: Towards an Integrated Perspective. International Journal of Bilingual Education and Bilingualism, Vol.7, (5), 381-397.

224 De Mejía, Anne-Marie. (2011). The national bilingual programme in Colombia: imposition or opportunity? Apples - Journal of Applied Language Studies Vol. 5(3), 7-17.

Díaz-Maggioli, G. (2012). Teaching Language Teachers: Scaffolding Professional Learning. (New York, NY): Rowman and Littlefield Publishers, INC. 
Escobar Alméciga, W. (2013). Identity-forming discourses: A critical discourse analysis on policy making processes concerning English language teaching in Colombia. PROFILE Issues in Teachers' Professional Development, 15(1), 45-60. Retrieved from $\mathrm{http}: / /$ www.revistas.unal.edu.co/index.php/profile/article/view/37861

Estacio, A. (2017). A decolonial perspective of the native and non-native dichotomy in English textbooks (Master dissertation). Retrieved from http://hdl.handle.net/11349/5671

Fairclough, N. (2003). Analysing discourse: Textual analysis for social research. London, UK: Routledge.

Fandiño-Parra, Y. (2014). Bogotá bilingüe: tensión entre política, currículo y realidad escolar. Educación y Educadores, 17(2), 215236. Retrieved from http://educacionyeducadores.unisabana.edu.co/ index.php/eye/article/view/3746/3555

Foucault, M. (2005). El orden del discurso. Alberto González T. (Trans.). Barcelona: Fabula Tusquets Editores.

González Moncada, A; Sierra Ospina, N; (2005). The professional development of foreign language teacher educators: another challenge for professional communities. Íkala, revista de lenguaje y cultura, 10() 11-39. Retrieved from http://148.215.1.176/articulo. oa? id $=255020409001$

González, A. (2007). Professional development of EFL teachers in Colombia: Between colonial and local practices. Íkala, revista de lenguaje y cultura, 12 (18), 309-332.

González, A. (2009). Who is educating EFL teachers: a qualitative study of in-service in Colombia. Íkala, revista de lenguaje y cultura, 8 (1), 153-172.

Graddol, D. (2006). English Next. Why Global English May Mean the End of "English as a Foreign Language". London: British Council.

Guerrero, C. \& Quintero, A. (2009). English as a Neutral Language in the Colombian National Standards: A Constituent of Dominance in English Language Education. Profile Issues in $\quad$ Te a c h e $r \mathrm{~s}$, Professional Development, 11(2), 135-150.

Guerrero, C. H. (2008). Bilingual Colombia: What does it mean to be bilingual within the framework of the national plan of bilingualism? PROFILE Issues in Teachers 'Professional Development, 10(1), 2745. 
Jóhanneson, I., Finnbogason, G., \& Geirsdóttir, G. (2000). In Lindblad, S., and Popkewitz, P. (Eds.), Public Discourses on Education Governance and Social Integration and Exclusion: Analysis of Policy Texts in European Contexts. (pp. 98-117). Uppsala Reports on Education $\mathrm{N}^{\circ} 36$.

Kachru, B. B. (1985). Standards, codification and sociolinguistic realism: The English language in the Outer Circle. In R. Quirk and H. Widdowson (Eds.), English in the World: Teaching and Learning the Language and Literatures (pp. 11-30). Cambridge: Cambridge University Press.

Kohn, K. (2011). English as a Lingua Franca and the Standard English misunderstanding. In A. Hower, \& A. Wilson (Eds.), English in Europe Today. Sociocultural and Educational Perspectives (pp. 7194). Amsterdam: John Benjamins Publishing Company.

Levis, J. (2005). Changing contexts and shifting paradigms of pronunciation teaching. TESOL Quarterly, 39, 369-377.

Lippi-Green, R. (2012). English with an accent: Language, ideology, and discrimination in the United States. New York: Routledge. 354 pages. ISBN-10:0415559103/ ISBN-13:978-0415559102

Lowenberg, P. H. (2000). Non-native varieties and the sociopolitics of English proficiency assessment. In J.K. Hall \& W. G. Eggington (Eds.), The sociopolitics of English language teaching (pp.67-82). Clevedon, UK: Multilingual Matters.

Mahboob, A. (2005). Beyond the native speaker in TESOL. In S. Zafar (Ed.), Culture, Context, \& Communication. (pp. 60-93). Abu Dhabi, United Arab Emirates: Center of Excellence for Applied Research and Training \& The Military Language Institute.

Mignolo, W. (2009). El Lado Más Oscuro del Renacimiento. Universitas Humanística (67), 165 - 203.

Muthanna, A., and Karaman, A.C. (2011). The need for change in teacher education in Yemen: the beliefs of prospective language teachers. Procedia Social and Behavioral Sciences 12(2011), 224226232

Nielsen, W., Triggs, V., Clarke, A., and Collins, J. (2010). The teacher education conversation: a network of cooperating teachers. Canadian Journal of Education / Revue canadienne de l'éducation, 33(4), 837868. 
Ninkovich, F. A. (1981). The Diplomacy of Ideas. US Foreign Policy and Cultural Relations, 1938-1950. Cambridge: Cambridge University Press.

Ordoñez, C.L (2011). Education for Bilingualism: Connecting Spanish and English from the curriculum, into the classroom, and beyond. PROFILE 13(2), 147-161.

Pennycook, A. (2004). Critical moments in a tesol praxicum. In B. Northon \& K. Toothey (Eds.), Critical pedagogies (pp. 327-345). Cambridge: Cambridge University Press.

Phillipson, R. (1992). Linguistic Imperialism. Oxford: Oxford University Press.

Pineda, C. (2001). Developing an EFL curriculum: an articulated framework. Colombian Applied Linguistics Journal 3(1), 6-20.

Popkewitz, T. S. (2000). The denial of change in the process of change: Systems of ideas and the construction of national evaluations. The Educational Researcher 29(1), 17-30.

Quijano, A. (1992). Colonialidad y Modernidad - Racionalidad [Coloniality and Modernity- Racionality]. In H. Bonilla (Ed.), Los conquistados, 1492 y la Población Indígena de las Américas (pp.437-447). Quito, Ecuador: Ediciones Tercer Mundo.

Ramanathan, V. (2013). A Postcolonial Perspective in Applied Linguistics: Situating English and the Vernaculars. Routledge: New York.

Ryan, P. (Lecturer). (2010, December). Don't insist on English! [TEDxDubai]. TED Talk. Podcast retrieved from https://www.ted. com/talks/patricia_ryan_ideas_in_all_languages_not_just_english

Sánchez, C., \& Obando, G. V. (2008). Is Colombia ready for "bilingualism"? PROFILE Issues in Teachers' Professional Development, 9(1), 181-195.

Seidlhofer, B. (2011). Understanding English as a Lingua Franca. Oxford: Oxford University Press.

Shohamy (2006). Language Policy: hidden agendas alld 1/Ctll approaches. London, UK: Routledge.

Shusterman, R. (2000). Performing live: Aesthetic alternatives for the ends of art. Ithaca, NY: Cornell University Press. 
Tollefson, J. (2000). Policy and ideology in the spread of English. In JK, Hall \& W. Eggington (Eds.), The sociopolitics of English language teaching (pp. 7-21). Clevedon, England, Tonawanda, NY: Multilingual Matters.

Usma, J. A. (2009). Education and language policy in Colombia: Exploring processes of inclusion, exclusion and stratification in times of global reform. PROFILE Issues in Teachers' Professional Development, 11(1), 123-142.

Valencia, M. (2013). Language policy and the manufacturing of consent for foreign intervention in Colombia. 27 PROFILE Vol. 15, No. 1, April 2013. ISSN 1657- 0790 (printed) 2256-5760 (online). Bogotá, Colombia. Pages 27-43.

Walkinshaw, I. \& Oanh, D (2014). Native- and Non-Native Speaking English Teachers in Vietnam: Weighing the Benefits. The Electronic Journal for English as a Second Language, 16 (3), 1-16.

Wenger, E. (1999). Communities of Practice: Learning, Meaning and Identity. Cambridge.

White, A. (1965). The British Council: The First 25 Years, 1934-1959. London: British Council. 
Authors

*Aura María Estacio Barrios works as an English teacher at Universidad de la Sabana. She supports the processes of designing and developing educational resources to teach English in a hybrid learning environment. She has worked as an English and French teacher in different higher education institutions such as Universidad Pedagógica Nacional and Universidad ECCI. She holds a Bachelor's degree in Foreign Languages Teaching (Spanish, English and French) from Universidad Pedagógica Nacional and a Master in Applied Linguistics to English Teaching from Universidad Distrital Francisco José de Caldas. Her research interests are discourse analysis, linguistic variations and decolonial studies

Jennyfer Paola Camargo Cely works as an English Teacher at Universidad de la Sabana. She supports the processes of designing and developing educational resources to teach English in a hybrid learning environment. She has also worked as an English teacher at Universidad Pedagogica Nacional and different K-12 schools. She holds a Bachelor's degree in English Teaching Education from Universidad Distrital FJC and a Master in Applied Linguistics from the same university. Her research interests are discourse analysis, bilingualism, and literacy practices. 